\title{
The Paradoxes of Macroeconomic Policies in Development Countries: The Case of Morocco
}

\author{
Ph.D. Badr Machrafi ${ }^{1}$ \\ Associate Researcher in Research laboratory on Finance, Entrepreneurship and Development, Mohammed V \\ University in Rabat (Morocco)
}

\begin{abstract}
Morocco has embarked on a process of formulating and implementing priority reforms aimed at improving the country's socio-economic environment. In this sense, it has put in place several strategies to promote economic activity and integrate its economy into the global economy. Consequently, the development and strengthening of the private sector has taken a major place on the basis of its role in the socio-economic development of the country. The promotion of investment and the encouragement of the private sector require not only the political commitment of the State but also the intervention of the main economic actors and a favorable socio-cultural environment. The purpose of this paper is therefore to explore recent developments in the Moroccan economy. To this end, we shall return to the major benchmarks of economic reforms espoused by Morocco. Later, we will deal with the Moroccan context by analyzing possible relationships that may exist between some macroeconomic indicators.
\end{abstract}

Keywords: Macroeconomics, Globalization, Development Country, Growth, Trade, Development strategy, Reforms, Development, Africa, Morocco New economic reforms, Economic context, Investment trends.

\section{Introduction}

Economic globalization is pushing the world's economies to be interdependent. This interdependence is accompanied by an increasingly pronounced opening of economies. Similarly, the interdependence of economies on an international scale increases economic risks. Nevertheless, the opening of an economy at the international level is necessary since it can be a source of growth and development ${ }^{2}$.

The geographical and cultural proximity of Morocco from Europe and the Middle East allows the kingdom to play an important role in trade and to position itself in the region and among the world economy. The desire to strengthen economic attractiveness and integrate the global economy, Morocco has embarked on the process of formulating and implementing priority reforms aimed at improving the social and economic environment of the country. These reforms have provided an image of change, modernization, improved and encouraged economic competitiveness, and sustained economic growth.

It should be noted that a new world economic order is emerging and the countries of the South play an increasingly important role. As pointed out by Chaponnière and Lautier "In the medium and long term, the likely continuation of a growth gap between the North and the South signals the continued shift in world trade. Extending current trends, South-South trade could account for half of world trade by 2020. For the economies of the South, this global rebalancing causes [...] a progressive distancing of the economies of the North and a strengthening of interdependencies South-South trade, sources of new tensions". ${ }^{3}$

However, the countries of the South have not had the same trajectory of economic development. Some countries have been very successful in exploiting their trade openness while others are still vulnerable to external shocks. These external shocks are felt much more in the nascent industries, the competitive sectors and the social level of the vulnerable populations. Indeed, Morocco has tried to connect its economy to the world economy via several economic cooperation agreements. This trade openness follows the implementation of the import substitution strategies adopted earlier. The failure of these strategies leads us to believe that a country's development strategy must be based on a long-term perspective, taking into account both economic constraints, social demands and the well-being of population. Economic reforms should therefore be attentive to

\footnotetext{
${ }^{1}$ Badr Machrafi is Doctor (PH.D) in Applied Economics. He is Associate Researcher in Research laboratory on Finance, Entrepreneurship and Development, Applied Economics and Sustainable Development , University Mohammed V in Rabat, Morocco. He is Lecturer in Macroeconomics in Faculty of Economics-Salél Mohammed V University in Rabat.

${ }^{2}$ Krugman P. R., La mondialisation n'est pas coupable: vertus et limites du libre-échange, Paris, La Découverte, 2000.

${ }^{3}$ Chaponnière J.-R. et Lautier M., « La montée des échanges Sud-Sud dans le commerce mondial », in CEPII, L'économie mondiale 2013, Paris, La Découverte, 2012, p. 101.
}

DOI: 10.9790/5933-0804014755 $\quad$ www.iosrjournals.org $\quad 47 \mid$ Page


developments in economic actors in order to improve the economic and institutional environment ${ }^{4}$ and to increase production and encourage foreign investment.

This work will begin with an observation and deepening of the global context based on the indicators. We will then present the reforms and the macroeconomic context of the business climate in Morocco.

\section{Trends in Growth and Foreign Direct Investment in the International Environment 2.1 Trend in the GDP growth rate}

Over the course of 2008 and the last three years, global economic conditions have been characterized by a slowdown due to the multiple crises, notably the subprime crisis, which has affected the US banking sector and is being shifted into an economic crisis. Indeed, several banks have bet on US subprime bonds that have been very profitable, and recently the sovereign debt crisis that affects the United States of America. The effects of these various shocks have weighed on the climate of global economic activity, particularly in terms of growth, inflation and unemployment.

The period following the global financial crisis between 2007-2009 (Table 1) experienced a downward trend in the GDP growth rate, which was not confined to advanced economies, as this trend was observed in all regions.

Table 1 : GDP growth (annual \%)

\begin{tabular}{|l|c|c|c|c|c|c|c|c|c|}
\hline & $\begin{array}{c}\text { North Africa } \\
\text { and the } \\
\text { Middle East }\end{array}$ & $\begin{array}{c}\text { South } \\
\text { Asia }\end{array}$ & $\begin{array}{c}\text { East Asia } \\
\text { and the } \\
\text { Pacific }\end{array}$ & Africa & $\begin{array}{c}\text { Latin } \\
\text { America and } \\
\text { the Caribbean }\end{array}$ & $\begin{array}{c}\text { North } \\
\text { America }\end{array}$ & $\begin{array}{c}\text { Europe } \\
\text { and } \\
\text { Central } \\
\text { Asia }\end{array}$ & $\begin{array}{c}\text { Central Europe } \\
\text { and the Baltic } \\
\text { States }\end{array}$ & $\begin{array}{c}\text { European } \\
\text { Union }\end{array}$ \\
\hline 2000 & 5,62 & 4,08 & 4,88 & 3,62 & 3,76 & 4,20 & 4,32 & 4,05 & 3,87 \\
\hline 2001 & 1,94 & 4,31 & 2,68 & 3,94 & 0,95 & 1,05 & 2,25 & 3,08 & 2,17 \\
\hline 2002 & 2,35 & 3,71 & 3,60 & 2,97 & 0,34 & 1,90 & 1,72 & 3,46 & 1,01 \\
\hline 2003 & 4,63 & 7,24 & 4,26 & 4,87 & 1,59 & 2,71 & 1,87 & 4,44 & 0,72 \\
\hline 2004 & 8,40 & 7,54 & 5,15 & 11,62 & 6,21 & 3,72 & 3,26 & 5,59 & 2,33 \\
\hline 2005 & 5,61 & 8,79 & 5,05 & 5,56 & 4,49 & 3,33 & 2,71 & 4,92 & 1,70 \\
\hline 2006 & 6,80 & 8,67 & 5,55 & 7,05 & 5,31 & 2,66 & 3,93 & 6,57 & 3,24 \\
\hline 2007 & 6,16 & 8,07 & 6,50 & 7,07 & 5,71 & 1,81 & 3,69 & 6,40 & 3,02 \\
\hline 2008 & 5,02 & 3,88 & 3,51 & 5,39 & 3,98 & $-0,17$ & 0,98 & 3,78 & 0,43 \\
\hline 2009 & 1,58 & 7,61 & 1,35 & 2,85 & $-1,72$ & $-2,79$ & $-4,50$ & $-3,69$ & $-4,52$ \\
\hline 2010 & 5,11 & 9,06 & 7,06 & 5,39 & 5,77 & 2,58 & 2,63 & 1,93 & 2,09 \\
\hline 2011 & 3,71 & 6,31 & 4,61 & 4,32 & 4,38 & 1,75 & 2,20 & 3,13 & 1,55 \\
\hline 2012 & 3,15 & 5,54 & 4,66 & 3,72 & 2,82 & 2,17 & 0,13 & 0,57 & $-0,91$ \\
\hline 2013 & 2,65 & 6,18 & 4,74 & 4,76 & 2,76 & 1,75 & 0,63 & 1,33 & $-0,26$ \\
\hline 2014 & 3,03 & 6,79 & 4,10 & 4,59 & 0,91 & 2,39 & 1,61 & 2,94 & 1,16 \\
\hline 2015 & 3,08 & 7,41 & 4,09 & 3,01 & $-0,18$ & 2,43 & 1,77 & 3,62 & 2,03 \\
\hline
\end{tabular}

Source: developed by the author using data from the World Bank

During the 2007-2009 crisis, the effects of financial shocks in the United States and the global financial crisis had negative effects on output. The impact of the crisis depends on the strength of the ties with the country from which the shock originates and its nature. Countries that have closer trade ties with the countries affected by the shock or use the currency of these countries in their trade have been more affected by the crisis than other countries. "Financial turmoil has had little direct impact on low-income countries, which are largely excluded from international financial markets, and emerging countries that have avoided large external deficits and accumulated large reserves In the years leading up to the crisis. Most emerging countries in Asia and Latin America were able to contain the rise in unemployment during the crisis and to achieve a rapid recovery in domestic demand, which led to the growth of their output in 2010. In the first quarter of 2010, some major emerging countries in these regions have even experienced double-digit growth rates"5.

After a period of recession due to the crisis, the growth rate of world GDP to return to the trend from 2010 in most regions, except for the euro area, where the recovery is much slower, (Greece, Portugal and

\footnotetext{
${ }_{5}^{4}$ Stiglitz J. E., La Grande désillusion, Paris, Fayard, 2002

${ }^{5}$ Rapport sur le commerce et le développement p.3, «Conférence des Nations Unies sur le commerce et le développement », Genève, 2010 
Spain), which allowed for a review of the economic strategies put in place by the European Union for these countries and the depreciation of the euro against the dollar.

According to the World Bank's World Economic Outlook, global economic growth is expected to strengthen to $2.7 \%$ in 2017 , thanks in particular to a recovery in manufacturing and trade, a renewed confidence in the markets and Stabilization of commodity prices, which enable emerging and developing countries to return to growth. In advanced economies, growth is expected to reach $1.9 \%$ in 2017, and in emerging and developing economies it will rise to $4.1 \%$ this year (from $3.5 \%$ in 2016$)^{6}$.

\subsection{Trends in foreign direct investment}

According to an UNCTAD report on investment ${ }^{7}$, the crisis has changed the distribution of foreign direct investment and destination areas. "Investments in developing countries and countries in transition have surged, with their share of global investment flows rising to 43\% in 2008. This increase is partly explained by a sharp decline in flows of investment to developed countries (29\%). In Africa, foreign investment has reached an unprecedented level, with West Africa carving out the lion's share with a 63\% increase over 2007, South-East Asia, South Asia and With an increase of 17\%, reached a new record; Investment in West Asia continued to increase for the sixth consecutive year; In Latin America and the Caribbean, the increase was 13\%; South East Europe experienced their eighth consecutive year of increase. However, in 2009, foreign direct investment fell in all regions of the world".

After the crisis, global foreign direct investment flows began to recover in 2010, with a slight increase globally, more than $\$ 1,200$ billion in 2010, reaching between 1,300 and 1500 billion dollars, and between 1600 and 2000 billion in 2012. Even with this recovery, the crisis has not put an end to the risks and uncertainties that weigh on the development and growth of the business environment, Economy is still fragile.

Global growth remains weak, its dynamics are changing and forecasts are likely to be further revised downwards. As a result, new challenges are emerging and contagion effects may become more of a concern.

On the other hand, the slowdown in growth of the main players in the global market such as the United States, the European Union or China will weigh on many other countries, notably emerging countries and developing countries that export commodities. On the other hand, long-standing problems, namely a fragmented financial system in the euro area and a disturbing public debt in all major advanced countries, such as the United States, remain unresolved and could lead to further crises. The global economic crisis brings us to the question of the effectiveness of stable state regulatory institutions and the need for stable governance.

According to the report of the World Trade Organization of the year 2013, the different growth dynamics in these different countries should react together to face the tightened inflationary pressures, for two reasons. First, the recovery in advanced economies will not lead to a major reduction in output gaps, which remain high. Second, commodity prices fell against a backdrop of increased supply and lower demand growth in the main emerging countries, notably China. The latest projections for fuel and non-combustible products show moderate declines in 2013 and subsequent years according to the International Monetary Fund. After falling considerably in 2015, foreign direct investment flows to the countries in transition are expected to recover somewhat.

Table 2 : Foreign Direct Investment (\% of GDP)

\begin{tabular}{|c|c|c|c|c|c|c|c|c|c|}
\hline & $\begin{array}{l}\text { North Africa } \\
\text { and the } \\
\text { Middle East }\end{array}$ & $\begin{array}{l}\text { South } \\
\text { Asia }\end{array}$ & $\begin{array}{l}\text { East Asia and } \\
\text { the Pacific }\end{array}$ & Africa & $\begin{array}{c}\text { Latin } \\
\text { America } \\
\text { and the } \\
\text { Caribbean }\end{array}$ & $\begin{array}{c}\text { North } \\
\text { America }\end{array}$ & $\begin{array}{l}\text { Europe } \\
\text { and } \\
\text { Central } \\
\text { Asia }\end{array}$ & $\begin{array}{l}\text { Central } \\
\text { Europe and } \\
\text { the Baltic } \\
\text { States }\end{array}$ & $\begin{array}{c}\text { European } \\
\text { Union }\end{array}$ \\
\hline 2000 & 1,30 & 0,70 & 2,11 & 1,90 & 3,67 & 3,79 & 7,68 & 5,52 & 8,21 \\
\hline 2001 & 0,87 & 0,90 & 1,66 & 4,57 & 3,45 & 1,76 & 3,65 & 4,61 & 3,82 \\
\hline 2002 & 1,02 & 0,94 & 1,44 & 3,01 & 3,01 & 1,14 & 3,68 & 5,02 & 3,90 \\
\hline 2003 & 1,83 & 0,61 & 1,47 & 3,00 & 2,38 & 0,95 & 2,76 & 3,22 & 2,74 \\
\hline 2004 & 2,60 & 0,81 & 2,06 & 2,14 & 3,09 & 1,58 & 2,78 & 5,44 & 2,87 \\
\hline 2005 & 4,81 & 1,03 & 1,83 & 2,90 & 2,88 & 1,15 & 5,91 & 6,01 & 6,56 \\
\hline 2006 & 6,18 & 2,12 & 2,70 & 2,07 & 2,91 & 2,36 & 6,79 & 8,01 & 7,12 \\
\hline 2007 & 6,00 & 2,18 & 3,25 & 3,25 & 3,46 & 2,89 & 8,65 & 11,91 & 9,36 \\
\hline 2008 & 4,37 & 3,38 & 2,73 & 3,70 & 3,31 & 2,48 & 5,31 & 9,09 & 5,63 \\
\hline
\end{tabular}

\footnotetext{
${ }^{6}$ Worldbank

${ }^{7}$ Conférence des nations unies sur le commerce et le développement, rapport sur l'investissement dans le monde, 2009 et 2010
} 
The paradoxes of macroeconomic policies in development countries: the case of Morocco

\begin{tabular}{|l|l|l|l|l|l|l|l|l|l|}
\hline 2009 & 3,52 & 2,38 & 1,97 & 3,63 & 2,21 & 1,11 & 2,86 & 2,43 & 2,61 \\
\hline 2010 & 3,15 & 1,55 & 2,93 & 2,10 & 3,37 & 1,74 & 3,32 & 1,56 & 3,41 \\
\hline 2011 & 1,97 & 1,79 & 2,84 & 2,69 & 3,56 & 1,71 & 4,30 & 3,42 & 4,64 \\
\hline 2012 & 1,76 & 1,21 & 2,46 & 2,29 & 3,49 & 1,63 & 4,06 & 2,88 & 4,25 \\
\hline 2013 & 1,68 & 1,42 & 2,78 & 2,28 & 3,23 & 1,86 & 3,00 & 1,06 & 3,37 \\
\hline 2014 & 1,52 & 1,56 & 2,80 & 2,55 & 3,49 & 1,42 & 2,08 & 3,71 & 2,14 \\
\hline 2015 & 1,74 & 1,85 & 2,80 & 2,62 & 3,76 & 2,22 & 3,46 & 1,89 & 3,40 \\
\hline
\end{tabular}

Source: developed by the author using data from the World Bank

In 2015, foreign direct investment in Africa declined by $7 \%$ from the previous year, with only \$ 54 billion. This is explained by the decline in commodity prices that has discouraged foreign direct investment in resource-rich countries. On the other hand, North Africa saw an increase in inflows of foreign direct investment, which offset the decline in investment in sub-Saharan Africa, especially in West and Central Africa.

From the World Bank's World Economic Outlook, by 2016, foreign investment in Africa is expected to increase modestly as a result of liberalization measures and planned privatizations of public enterprises.

Regarding flows of foreign direct investment to developing Asia increased by $16 \%$, with a new record of \$ 541 billion. This strong increase is largely explained by the results of the countries of East Asia and South Asia. Foreign direct investment inflows are expected to weaken in 2016 and fall to their 2014 levels. Foreign direct investment inflows from the region's countries fell by about 17 per cent to $\$ 332$ billion - Decline since $2012^{8}$.

\section{The macroeconomic context of doing business in Morocco}

To develop economic activity and integrate into the global economy, Morocco has embarked on the process of formulating and implementing priority reforms aimed at improving the country's social and economic environment.

\subsection{New economic reforms in Morocco}

The desire to strengthen economic attractiveness and integrate the world economy, Morocco has implemented reforms that have allowed us to give an image of change, modernization, improve and encourage economic competitiveness, and Support economic growth. The geographical and cultural proximity of Morocco from Europe and the Middle East allows the kingdom to play an important role in trade and to position itself in the region and among the world economy.

In a context of liberalization and integration into the world economy, Morocco has committed itself to helping build a stable business climate with a reliable legislative and institutional framework with a group of laws in order to make them conform to international standards (example of the Competition and Price Freedom Act, which establishes rules for the control of pricing policies and consumer protection). The Kingdom set up the National Committee for the Business Environment (CNEA) in December 2009, which aims to strengthen inter-ministerial coordination and public-private dialogue, and to establish strategic steering of reforms. It is part of the National Pact for Industrial Emergence and has four main objectives:

$\checkmark$ Simplify and strengthen the transparency of administrative procedures;

$\checkmark$ Modernize business law;

$\checkmark$ Improve resolution of commercial disputes;

$\checkmark$ Improve consultation and communication on reforms

Following the policy of regionalization launched by Morocco. In 2002, the Kingdom created the Regional Investment Centers. Their functioning is adapted to the policy of regionalization; they are intended to facilitate the creation of business and investment. The IRCs can coordinate and complement the operation of the Moroccan Investment Development Agency (AMDI).

Morocco's openness to the world economy has been reflected in free trade agreements with:

$\checkmark$ the European Union, which entered into force on 1 March 2000, which is the main trading partner of the Kingdom and an advanced status, granted in 2008, which is marked by a legislative and regulatory status that allowed Morocco to integrate The internal market of the European Union;

$\checkmark$ Morocco signed with the United States of America (concluded in 2004);

$\checkmark \quad$ The United States of America, which was signed in 2004 and came into force in 2006 and is characterized by being a comprehensive exchange agreement;

\footnotetext{
${ }^{8}$ http://unctad.org/fr/PublicationsLibrary/wir2016_Overview_fr.pdf

DOI: 10.9790/5933-0804014755 $\quad$ www.iosrjournals.org $\quad 50 \mid$ Page
}


$\checkmark$ Morocco has also signed an agreement with the Mediterranean Arab countries to strengthen regional economic integration with several countries: Egypt, Jordan and Tunisia. It is implemented on 27 March 2007, but it is facing difficulties in its implementation. So with other African countries, with the aim of encouraging and encouraging the exports of Moroccan products.

Morocco has launched several sectoral strategies to promote all sectors of economic activity:

$\checkmark$ The agricultural sector, with the Green Morocco Plan, which is interested in increasing production and encouraging exports of agricultural products;

$\checkmark$ The Halieutis Plan is a plan designed to develop and strengthen martin and fish farming;

$\checkmark \quad$ To encourage and develop the craft sector, Morocco has established the Vision 2015 Plan;

$\checkmark$ The development of tourism has also played a part in the strategies developed by the Kingdom, which is one of the sectors that help the growth of the national economy.

$\checkmark$ To reduce the energy bill, Morocco has put in place Plan Energy tries to develop renewable energies by adapting a Solar Plan in March 2010.

$\checkmark \quad$ For the logistics sector, Morocco has developed a strategy to strengthen infrastructure such as the port of Tangier Med, which has become one of the main ports on an international scale and adopting a Logistics Plan to organize and boost the sector.

$\checkmark \quad$ To develop e-government and reduce the digital divide by adopting the Morocco Numeric 2013 Plan, an EMorocco strategy was launched in 2009.

$\checkmark$ In May 2005, Morocco implemented the National Initiative for Human Development (INDH) in order to reduce social deficits for people with high vulnerability or specific needs and the promotion of incomegenerating activities.

Even with all these diversifications that reflect the integration of Morocco into the rails of growth and integration into the global economy. These strategies have experienced implementation difficulties and lack of consistency.

\subsection{The macroeconomic context in Morocco}

In the macroeconomic context, in addition to its advanced status with the European Union, Morocco has set up so-called sectoral development strategies aimed at developing the business climate in the Kingdom. In general, the impact of the crisis varies according to their degree of integration with the world economy, and the soundness of the financial system. According to a study carried out by the High Commission for Planning, on 30 June 2010, the Moroccan economy was able to escape from the financial crisis of 2007 due to two main reasons: the weak integration of the Moroccan economy into the world system and the Regulatory framework of the Moroccan financial system complies with prudential rules example Basel II.

The Moroccan economy felt the effects of the crisis on its main sectors, which are of great importance for the development and growth of the economy, were directly affected by the crisis.

Figure 1 : Volatility of the growth rate in Morocco

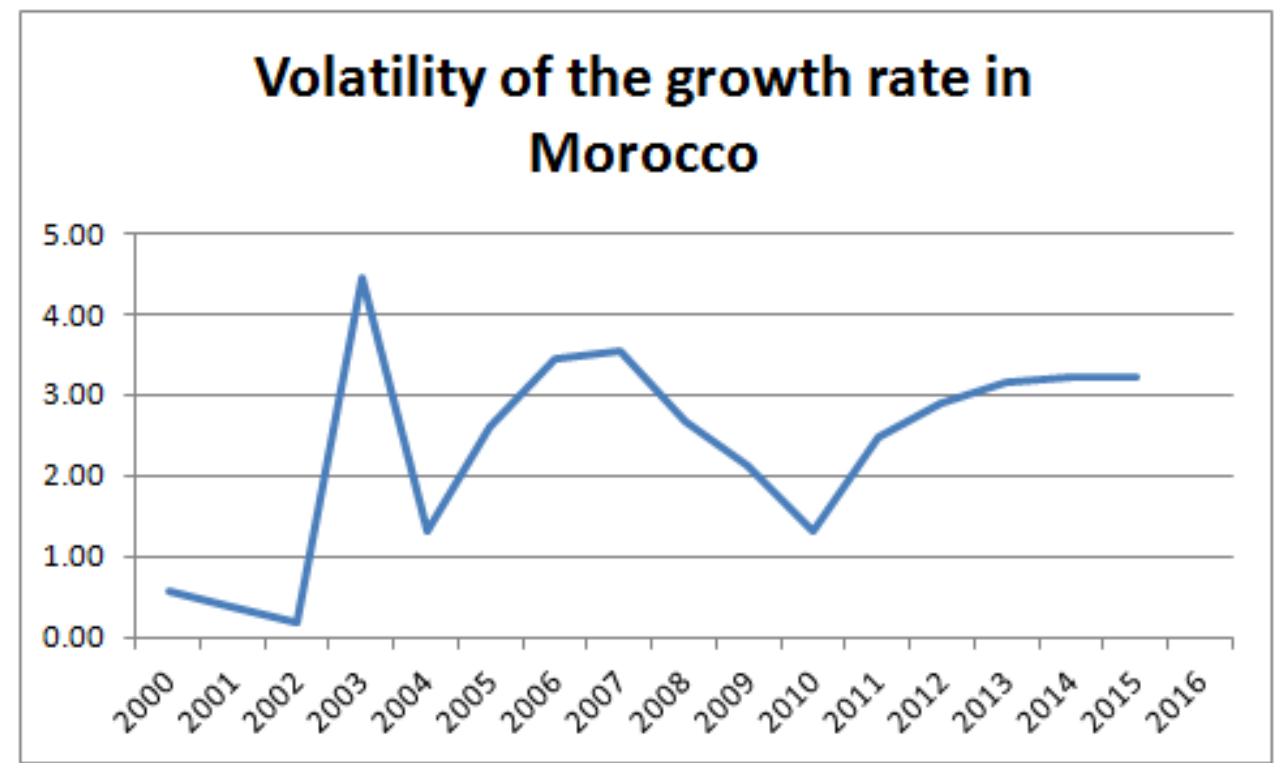

Source: developed by the author using data from the World Bank 
Moroccan economic growth remains dependent on the vagaries of the weather. Following the good harvest in 2009, the farming campaign of 2009-2010 was marked by a good trend, with a $22 \%$ increase compared to the average of the past five years. The secondary and tertiary sectors were the main sectors that boosted growth in 2010 excluding the agricultural sector.

After a record cereal production in 2015, Morocco experienced a severe drought in 2016. Agricultural production, which still accounts for around $15 \%$ of the country's GDP, declined by about $10 \%$.

The Moroccan economy continued its trend in 2011, with real GDP growth of 5\%, which was driven by a 5.6\% increase in non-agricultural GDP. On the other hand, GDP growth in 2012 was estimated at $3.6 \%$ due to unstable global demand and average agricultural activity. Despite this, 2013 will be a year of growth recovery, which will be adjusted to around 5\% according to OECD forecasts. Nevertheless, the forecasts were optimistic following the particular political climate and uncertainties about the composition of the new government in the second half of 2013.

According to the Ministry of Tourism, the tourism sector, which is one of the sources of foreign exchange for the country, experienced a slight increase of $2 \%$ in 2009 . Overnight stays in accommodation establishments decreased of $1.4 \%$ and tourism revenues decreased by $5 \%$, which seems to be less affected by the crisis. In 2010, travel receipts and tourist arrivals increased by more than $6.8 \%$ and $11 \%$ respectively in 2009 , followed by an increase of more than $4.4 \%$ and $0.6 \%$ in 2011 . Against travel receipts fell in 2012 by less than $1.7 \%$ and tourist arrivals increased by more than $0.4 \%$ even with the crisis that affected the European Union and the wars that took place in the region Mediterranean countries, Morocco has been able to control and stabilize the development of the sector.

The investment rate, which rose sharply to $30 \%$ of GDP in 2007, experienced some setbacks during the crisis period. This had an effect on the unemployment rate, which rose from $9.6 \%$ in 2008 to $9.1 \%$ in 2009 . The tourism sector was also affected by the decline in foreign direct investment. The latter declined by $26.3 \%$ and $29.2 \%$ respectively in 2008 and 2009 , respectively.

Following the recession of the country's main partners (France and Spain), transfers of Moroccans residing abroad fell by $3.5 \%$ in the fourth quarter of 2008, resulting in a 5,4\% of transfers of Moroccans residing abroad in $2009^{9}$ against an annual growth of $7.4 \%$ between the period $2002-2007$, with a $15 \%$ increase in 2007.

In 2012, the Moroccan economy went through a very difficult period due to the increase in the price of energy products, compensation expenses rose $12 \%$ to reach 55 billion dirhams ${ }^{10}$ which exacerbated the external imbalances And fiscal, which has impacted economic growth. According to the governor of Bank Al Maghrib, the rate of economic growth in 2012 reached $2.7 \%$ following the decline in global growth and the crisis that affected the main partners of the Kingdom. This is due to the growth of the services sector as well as the increase in domestic demand, although the rate of inflation did not exceed $1.3 \%$.

Following the annual report of the Economic, Social and Environmental Council, "the current account of the balance of payments recorded significant deficits, reaching 9\% of GDP after 8\% in 2011". This means that foreign assets represent just four months of imports at the end of 2012 instead of five months at the beginning of the same year.

Faced with this situation, the State has sought facilities from the international financial institutions with a view to ensuring and controlling the external balance. To this end, the IMF has allocated an amount equivalent to $\$ 6.2$ billion.

Agricultural activity made it possible to cushion the crisis with its good companion who stabilized employment in the rural environment following the strategies launched by Morocco in the field of agriculture. According to the High Commissioner for the Plan, "Agricultural added value in volume increased by $22.8 \%$ in the second quarter of 2013 instead of the decrease $9.5 \%$ the same quarter of the previous year".

The Moroccan economy, despite the negative effects of the economic crisis, has shown its capacity for resilience. The process of transformation of Morocco is progressing and is already part of a long-term scenario that takes advantage of the experience of the development of the economy, social and human capital. The opening-up of the world economy, the liberalization movement and the evolution of the financial system in general, and the banking system in particular, have influenced the evolution and dynamics of economic growth.

The following graph shows the evolution of foreign direct investment in relation to gross domestic product. According to which, investments have shown their best evolution relative to gross domestic product in 2007 with $0.84 \%, 0.64 \%$ in 2010 and $0.38 \%$ in 2012 .

\footnotetext{
${ }^{9}$ Haut Commissariat au Plan, « Impact de la crise mondiale sur l'économie marocaine », Haut Commissariat au Plan, 30 juin 2010

${ }^{10}$ Annual report of the Economic, Social and Environmental Council, 2012

DOI: 10.9790/5933-0804014755 www.iosrjournals.org


Figure 2 : Trends in foreign direct investment in Morocco relative to GDP

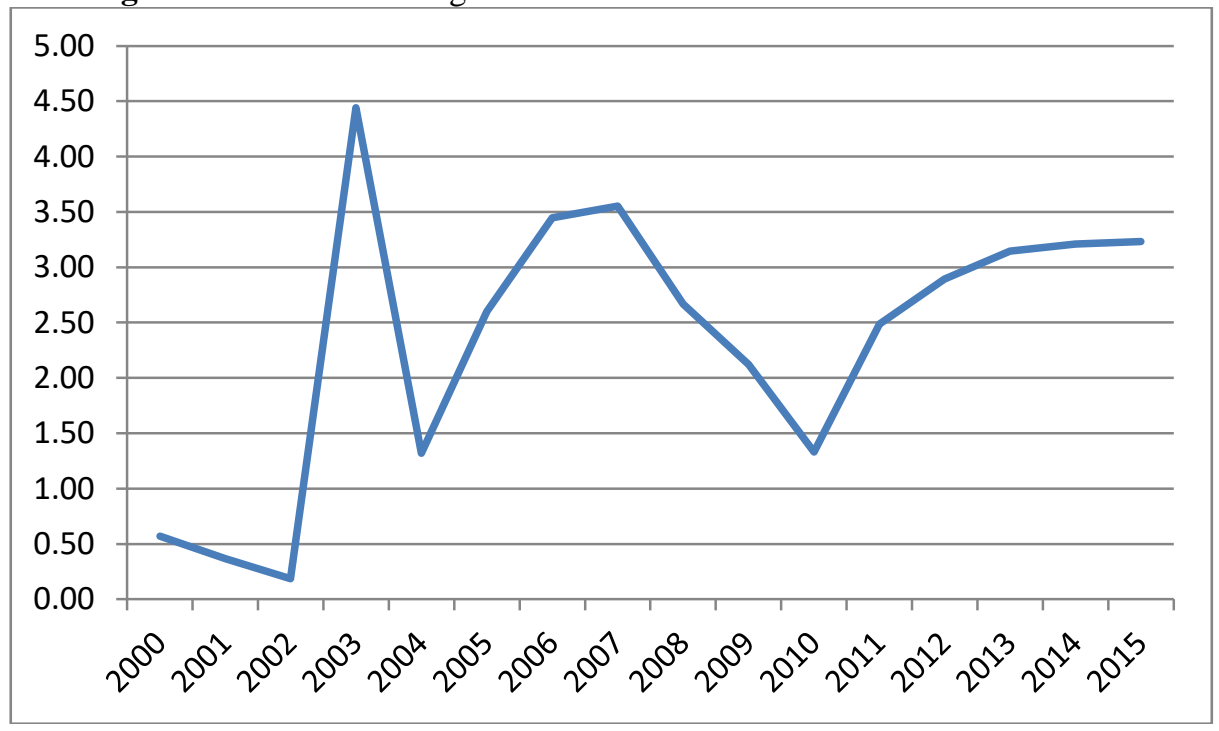

Source: developed by the author using data from the World Bank

This development of foreign direct investment is linked to the government's efforts to create an enabling environment and improved economic conditions which allowed Morocco to increase its inflows of foreign direct investment by a significant and gradual increase by six between 2002 and 2007 according to an OECD report.

Despite large public investments made in recent years, the non-agricultural sector remains sluggish, with a growth rate of around $3 \%$. Unemployment has declined slightly to $9.4 \%$, but this development masks a prolonged decline in the rate of participation in the labor market, which today is well below $50 \%$. An estimated 1.7 million young people aged 15 to 24 who were out of school, unemployed or not in training by 2016 . The currency exchange rate is determined by Reference to a basket of Euros and US dollars; inflation is contained at less than $2 \%$.

The pursuit of prudent macroeconomic policies has helped to reduce external and fiscal imbalances in recent years. Coupled with robust fiscal management and financial control, the completion of the subsidy reform begun in 2014 has helped further reduce the budget deficit to an estimated 3.9\% of GDP by 2016 and stabilize public debt around $66 \%$ of GDP.

The improvement in the public investment ratio and the fall in world oil prices have contributed to a considerable reduction in the current account deficit in recent years; A trend reversed only in 2016 as a result of an accommodative monetary policy and a recovery in private sector investment lending. Due to the persistence of large foreign direct investment flows, Morocco's foreign exchange reserves increased to 6.4 months of imports of goods and services by the end of 2016.

The process of transformation of Morocco is progressing and is already part of a long-term scenario that takes advantage of the experience of the development of the economy, social and human capital. But the impact of globalization on our daily lives has positive and negative consequences on production, economic growth, human and social development.

Yet Morocco is willing to pursue prudent macroeconomic policies and implement structural reforms to strengthen the business environment, modernize public administration and improve access to quality public services, among others. The gradual shift to a more flexible exchange rate regime announced by Al-Maghrib Bank from July 2017 is also expected to help strengthen Morocco's competitiveness. The programmed implementation of the organic finance law and the decentralization process should make it possible to strengthen the governance and efficiency of the public sector and, overall, annual GDP growth should reach its current potential of $4 \%$ on average. Moreover, it is unlikely that this positive trend will translate into significant improvements in the structure of the labor market.

Based on its geographical, historical and cultural characteristics as well as success and experience in social and economic development. Morocco must adopt an openness strategy to rebuild its partnerships by diversifying its partners and its production in the field of new technology. But, by adopting a regional dimension (for example, Morocco-Africa, Morocco -Union of the Arab Maghreb or Morocco -Mediterranean country).

In this perspective, Morocco must take advantage of the opportunities open to it and remain attentive on the evolution of the scenarios and difficulties that affect the world. It will be necessary to seek and integrate more and more to other markets in order to position itself in the world market. 
Books:

\section{Bibliography}

[1]. Achy L., L'économie marocaine en question, Paris, L'Harmattan, 2007

[2]. Aglietta M., La crise : Pourquoi on en est arrivé là ? Comment en sortir ?, Paris, Editions Michalon, 2008

[3]. Aktouf O., La stratégie de l'autruche Post-mondialisation, management et rationalité économique, Montréal, Éditions Écosociété, 2002

[4]. Attali J., La Crise, et après ?, Paris, Fayard, 2009.

[5]. Béchu T., Economie et marchés financiers : perspectives 2010-2020, Éditions d'Organisation, Groupe Eyrolles, 2010

[6]. Bourgain A., Brot J., Gérardi H., L'intégration de l'Afrique dans l'économie mondiale, Editions Karthala, 2014

[7]. Chaponnière J.-R. et Lautier M., « La montée des échanges Sud-Sud dans le commerce mondial », in CEPII, L'économie mondiale 2013, Paris, La Découverte, 2012

[8]. Combe E., La politique de la concurrence, Paris, Éditions La Découverte, 2002

[9]. Kiani K. M. , Business Cycle Fluctuations and Economic Policy, New York, Nova Science Publishers, 2009

[10]. Krugman P. R., Obstfeld M., Economie internationale, $4^{\mathrm{e}}$ édition, Editions De Boeck, 2004

[11]. Krugman P. R., La mondialisation n'est pas coupable Vertus et limites du libre-échange, Paris, Editions La Découverte, 2000.

[12]. Lacoste O., Comprendre les crises financières, Editions Groupe Eyrolles, 2009.

[13]. Machrafi B., Conjoncture Econonomique et système bancaire marocain, (1980-2013), Ph.D. Thesis, Mohammed V University in Rabat, November 2016.

[14]. Mouhoubila S., Face cachée de la crise financière mondiale, Editions L'Harmattan, 2009.

[15]. Ost C., Hamaide C., L'économie en mouvement : outils d'analyse de la conjoncture, $2^{\mathrm{e}}$ édition, Editions De Boeck, 1996

[16]. Rainelli M., Le commerce international, $9^{\mathrm{e}}$ édition, Paris, Éditions La Découverte, 2003

[17]. Stiglitz J. E., La Grande désillusion, Paris, Editions Fayard, 2002

\section{Papers and report:}

[18]. Abdelmoumni F., Akesbi N., Balafrej O., Bouabid A., Bouabid A., Charafi Y., Elhariry K., El Mesbahi K., Guedira N., Rachidi D., Rharbaoui O. et Tazi K., «Le Maroc a-t-il une stratégie de développement économique ? Quelques éléments de réflexion pour un véritable décollage économique et social », Fondation Abderrahim Bouabid, Juin 2010.

[19]. Agénor, P.R. and El Aynaoui, K. Morocco: Growth strategy for 2025 in an evolving international environment. Books \& Reports. OCP Policy Center. number 978-9954-35-175-8., 2015.

[20]. Agénor, P.R., O. Canuto, and M. Jelenic.. Avoiding middle-income growth traps. World Bank Economic Premise, 2012

[21]. Aitken, B. J., and Harrison, A. E., Do domestic firms benefit from direct foreign investment? Evidence from Venezuela. The American Economic Review. 89, 1999

[22]. Institut Amadeus, « Le Maroc en Afrique : la voie royale », Institut Amadeus, 2015

[23]. BAM (Bank Al-Maghrib) and (CESE) Economic, Social and Environmental Council. 2016. "Richesse Globale du Maroc entre 1999 et 2013." Unpublished. Kingdom of Morocco.

[24]. Bank Al Maghrib, Enquête mensuelle de conjoncture dans l'industrie, Mars 2009

[25]. Bank Al Maghrib, Rapport de Bank Al-Maghrib sur l'exercice de 2015

[26]. Bank Al Maghrib, Rapport sur la politique monétaire, $n^{\circ}$ 10/2009, 24 mars 2009

[27]. Bank Al Maghrib, Résultats trimestriels de l'enquête mensuelle de conjoncture, 1er trimestre 2009

[28]. Bank Al Maghrib, Revue mensuelle de la conjoncture économique, monétaire et financière, Avril 2009

[29]. Banque Mondiale, « Promouvoir la croissance et l'emploi dans le Royaume du Maroc », Banque Mondiale, New Yourk, 2006

[30]. Becker, Gary S. 1962. "Investment in Human Capital: A Theoretical Analysis.” Journal of Political Economy 70 (5): 9-49.

[31]. Benabdejlil, Nadia, Yannick Lung, and Alain Piveteau. 2016. "L'émergence d'un pôle automobile à Tanger (Maroc)." Cahiers du GREThA, n²016-04.

[32]. Billaudot B., «La dynamique macro-économique de l'économie marocaine (1986-2003) Etat de lieux », Critique économique, $\mathrm{n}^{\circ} 15$, hiver-printemps 2005, p3-p49

[33]. Chauffour J-P, «Résumé: Le Maroc à l'horizon 2040 - Investir dans le capital immatériel pour accélérer l'émergence économique », Directions du développement, Groupe de la Banques Mondiale, 2017

[34]. Chauffour J. P. et Sekkat K., «De l'éveil politique à l'éveil économique dans le monde arabe : la voie de l'intégration économique », Rapport sur le commerce et l'investissement direct étranger pour le Partenariat de Deauville, mai 2012

[35]. Centre de Développement de l'Organisation de Coopération et de Développement Economiques, « Maroc », in Perspectives économiques en Afrique 2013, Éditions OCDE, 13 Juin 2009

[36]. Centre de Développement de l'OCDE, « Maroc », in Perspectives économiques en Afrique 2013, Éditions OCDE, 09 Juin 2010

[37]. Centre de Développement de l'OCDE, «Maroc », in Perspectives économiques en Afrique 2013 : L'Afrique et ses partenaires émergents, Éditions OCDE, 06 Juin 2011

[38]. Centre de Développement de l'OCDE, « Maroc », in Perspectives économiques en Afrique 2013 : Promouvoir l'emploi des jeunes, Éditions OCDE, 28 Mai 2012

[39]. Centre de Développement de l'OCDE, « Maroc », in Perspectives économiques en Afrique 2013: Transformation structurelle et ressources naturelles, Éditions OCDE, Aout 2013

[40]. Clark J. M., "Strategie Factors in Business Cycles", New-York, National Bureau of Economic Research, 1935, p. 4-5

[41]. CNUCD, «Le développement économique en Afrique, La coopération Sud-Sud l'Afrique et les nouvelles formes de partenariat pour le développement », Nations Unies, 2010

[42]. CNUCD, « Le développement économique en Afrique, Commerce intra-africain : libérer le dynamisme du secteur privé », Nations Unies, 2013

[43]. CNUCD, «Le développement économique en Afrique, Chapitre 5 : transformation structurelle et développement durable en Afrique », Nations Unies, 2012

[44]. CNUCED et de l'ONUDI, « Le développement économique en Afrique, Promouvoir le développement industriel en Afrique dans le nouvel environnement mondial », Nations Unies, 2011

[45]. El Mokri, Karim. 2016. "Le défi de la transformation économique structurelle: une analyse, par la complexité économique. “ Research Paper Series, OCP Policy Center.

[46]. Eggoh J. C., « Développement financier, instabilité financière et croissance économique : un réexamen de la relation », Région et Développement, $\mathrm{n}^{\circ} 32-2010$

[47]. Eggoh J. C., « Développement financier et croissance : une synthèse des contributions pionnières », Document de Recherche $\mathrm{n}^{\circ}$ 2009-18, Laboratoire d'Economie d'Orléans, Faculté de Droit, d'Economie et de Gestion, http://www.univ-orleans.fr/DEG/LEO

[48]. Fischer S., "The Role of Macroeconomic Factors in Growth”, Journal of Monetary Economics, vol. 32, n³, 1993 , p. 485-511.

DOI: 10.9790/5933-0804014755 www.iosrjournals.org 54 Page


[49]. Fonds Monétaire International, Études économiques et financières- Perspectives de l'économie mondiale : La reprise s'affermit, mais reste inégale, FMI, Avril 2014

[50]. Gaffard J-L., « De l'équilibre à la séquence : la méthode d'analyse économique dynamique de Hicks », dans « J. R. Hicks, une œuvre multidimensionnelle », Cahiers d'économie Politique Histoire de la pensée et théories, n 39 - automne 2001, L'Harmattan, p. $161-174$

[51]. Haddad, M. and Harrison, A.. Are there positive spillovers from direct foreign investment? Evidence from panel data for Morocco. Journal of Development Economics. 42. 1993

[52]. Haut Commissariat au Plan, «Impact de la crise mondiale sur l'économie marocaine », Haut Commissariat au Plan, 2010

[53]. Haut Commissariat au Plan, « Les sources de la croissance économique au Maroc », Haut Commissariat au Plan, Septembre 2005

[54]. Haut Commissariat au Plan, « Croissance économique et développement humain Eléments pour une planification stratégique 2007$2015 »$, Haut Commissariat au Plan, Juin 2007

[55]. Haut Commissariat au Plan, «Prospective Maroc 2030, Maroc 2030 dans l'espace Maghreb : approches d'une nouvelle géographie économique », Haut Commissariat au Plan

[56]. Haut Commissariat au Plan, « Prospective Maroc 2030, Tourisme 2030 : quelles ambitions pour le Maroc ?», Haut Commissariat au Plan

[57]. IRS, «Le Maroc face à la crise financière et économique mondiale : enjeux et orientations de politiques Publiques », Institut Royal des Etudes Stratégiques, mai, 2009

[58]. Joumady O., «Efficacité et productivité des banques au Maroc durant la période de libéralisation financière 1990-1996 », 17 èmes Journées Internationales d'Economie Monétaire et Bancaire, Lisbonne, 7-9 juin 2000

[59]. Juglar C., « Crises commerciales », extrait du dictionnaire général de la politique par Maurice M. Block, 1863

[60]. King R. G. \& Levine R., « Finance and Growth: Schumpeter Might Be Right », Quarterly Journal of Economics, vol. 108, n³, 1993, p.717-738

[61]. Ministère de l'Economie et des Finances, Système financier marocain : Pour une convergence accélérée vers les standards de l'Union Européenne, Direction des Etudes et des Prévisions Financières, Mars 2008

Ph.D. Badr Machrafi. "The Paradoxes of Macroeconomic Policies in Development Countries: The Case of Morocco." IOSR Journal of Economics and Finance (IOSR-JEF) 8.4 (2017): 47-55. 